\title{
Validation of BANCS model for assessing stream bank erosion hazard potential (SBEHP) in Bakreshwar River of Rarh region, Eastern India
}

\author{
Krishna Gopal Ghosh ${ }^{1} \cdot$ Swades $_{\text {Pal }^{2}} \cdot$ Sutapa Mukhopadhyay $^{3}$
}

Received: 27 April 2016/ Accepted: 4 June 2016/Published online: 14 June 2016

(C) Springer International Publishing Switzerland 2016

\begin{abstract}
It is often difficult to assess stream bank erosion. Bank Assessment for Non-point source Consequences of Sediment (BANCS) model is a renowned procedure for evaluating Stream Bank Erosion Hazard Potential (SBEHP). In the present article inventory of stream bank condition have been assessed from field surveys on 24 sample segment over a consecutive 5 year period for $86.36 \mathrm{~km}$ stretched river Bakreshwar of Eastern India. Bank Erosion Hazard Index (BEHI), Near Bank Stress (NBS) and field based data have been considered for this appraisal. The results show that (1) BEHI is high in the upstream and near the confluence segments. (2) Compare to BEHI, NBS is less for most of the sites. (3) Fragile lateritic soil, sparse vegetation, etc., in the upstream and steep slope and barren bank, sinuous channel, loosely compact alluvial sediments, etc., in the downstream can be accountable for high SBEHP in those counterparts. (4) On the annual basis, a total of about 173595.75 metric tons of sediment entrains into the river from banks. (5) Banks have experienced varied rate of erosion from similar BEHI-NBS combinations. Therefore, we concluded that BEHI and
\end{abstract}

Krishna Gopal Ghosh

k.g.ghosh@india.com

Swades Pal

swadeshpal82@gmail.com

Sutapa Mukhopadhyay

sutapageo@gmail.com

Santiniketan 731235, West Bengal, India

2 Department of Geography, University of Gour Bango, Malda 732103, West Bengal, India

3 Department of Geography, Visva-Bharati (A Central University), Santiniketan 731235, West Bengal, India
NBS is potentially not a sound bank erosion hazard predictive model for our present study.

Keywords Bank assessment for non-point source consequences of sediment (BANCS) - Bank erosion hazard index (BEHI) - Stream bank erosion hazard potential (SBEHP) · Near bank stress (NBS) · BEHI-NBS matrix calibration $\cdot$ Bank erosion

\section{Introduction}

Stream bank erosion is a complex natural process operating in a channel scale. Greater erosion accelerates sedimentation rates and contaminates entering into water resources. Up to $80 \%$ of total sediment loading in world's streams is directly related to stream-bank erosion (Bull 1997; Simon and Darby 1999; Sekely et al. 2002; Evans et al. 2006; Fox et al. 2007). Worldwide, erosion from bank is one of the most insidious non-point source pollutants entering into the freshwater (Boggess et al. 1980; NYCDEP 2007; US-EPA 2009). Increased sediment supply due to bank erosion has multifarious effect on hydro-eco-morphological functioning of a river (Dudley and Karr 2002). Example includes (1) sedimentation of reservoirs (Beach 1994; Hargrove et al. 2010) and consequent loss of water storage capacity (Beach 1994; Williams and Smith 2008; Hargrove et al. 2010), (2) amplify flooding potential (Thorne 1999) and channel instability (Rosgen 1996, 2001, 2006, 2008a, b; Knighton 1998), (3) enhance ambient water temperature (Naiman and Decamps 1997), reduce dissolved oxygen in streams (Ringler and Hall 1975) causing loss of stream habitat and biotic diversity (Odum 1971; Naiman and Decamps 1997), (4) raise water treatment costs (Boggess et al. 1980; Williams and Smith 2008) as well as lessen 
aesthetic and recreational value (Riley 2008; Williams and Smith 2008). Thus, it is imperative to apprehend streambank erosion processes and revise erosion hazard potential which may allow us to take future bank stabilization efforts, mitigate sediment pollution to our freshwater resources.

Extensive research has been underway on stream bank erosion mechanics, stream bank stability analysis and prediction. Thorne (1982, 1999); Simon and Thorne (1996); Darby and Thorne (1996); Simon et al. (1999); Simon (1989, 1992); Schumn and Lichty (1963), etc., are some pioneer scholars in this connection. However, significance of bank erosion that contributes sediment to the total annual sediment transport has often been overlooked in most studies. A practical method for evaluating erodibility potential of stream banks and computing stream bank erosion rates and consequent sediment loading is the Bank Assessment for Non-point source Consequences of Sediment (BANCS) model, which encompasses two quantitative tools Bank Erosion Hazard Index (BEHI) (Rosgen 1996, 2001, 2006, 2008a, b) and Near-Bank Stress (NBS) (Rosgen 1996, 2001, 2006, 2008a, b, 2001, 2006). This model has widely been used by several scholars in different regions of the world such as, Arkansas (Van Eps et al. 2004), Minnesota (Nieber et al. 2008), Lower Coeur d'Alene (Nelson et al. 2009), Northeast Kansas (Sass 2011), West Tripura (Bandyopadhyay et al. 2013).

The present study has sought to (1) explore sample segment specific stream bank erosion hazard potential and (2) establish a baseline dataset to predict an annual stream bank erosion rate of river Bakreshwar using Rosgen's BANCS model due to its relative simplicity. The use of the BANCS model has applied for $86.36 \mathrm{~km}$ long river Bakreshwar of Eastern India. 24 sample segments from seven stream reaches of the river have been measured and monitored from 2010 to 2015. In addition, the work aims to provide a curve that can predict annual stream bank erosion rates and sediment contributions from channel banks of river Bakreshwar. It is expected that the curve could be used in similar hydro-physiographic regions. The ultimate goal is to assist in formulating future stream management strategies by assessing stream bank erosion.

\section{Geographic location and regional settings of the study area}

Bakreshwar River is 5th order tributary of the river Kopai (Kuya) and a part of Mayurakshi river system of Eastern India. The catchment area (about $714.56 \mathrm{~km}^{2}$ ) is a part of lateritic Rarh plain region enclosed between $23^{\circ} 43^{\prime} 23.28^{\prime \prime} \mathrm{N}$ to $23^{\circ} 56^{\prime} 31.16^{\prime \prime} \mathrm{N}$ latitudes and $87^{\circ} 17^{\prime} 1.59^{\prime \prime} \mathrm{E}$ to $87^{\circ} 47^{\prime} 16.07^{\prime \prime} \mathrm{E}$ longitudes and lies in between the River Mayurakshi of North and Kuya of the South. The river originates from a large pond, flows through the hot springs of Bakreshwar and joins River Kopai.

The entire catchment area of the river Bakreshwar entertains 34 th order, 133 rd order 54 2nd order and 318 st order streams to drain. Total length of the river is $86.36 \mathrm{~km}$ of which about $13.87 \mathrm{~km}$ is perennial. In most of the part of lower Bakreshwar, channel width is less but depth is more, channel meandering is prominent, even channel bifurcation is also evident along with heavy siltation and channel clogging in some cases (Ghosh 2015). Flood incidence is common particularly in the lower catchment during peak monsoon period. Discharge from Nil-Nirjon dam and additional influx of water through canals from other river system encourage flood incidences particularly in the lower part of the river basin (Ghosh 2015).

On considerations of relief (mean elevation is $194.47 \mathrm{~m}$ and relative relief is of 142 to $24 \mathrm{~m}$ ), the river basin is primarily a part of the farthest eastern extension of the Chotonagpur Plateau in the West and Moribund Delta in the East and often referred to Rahr Bengal (Bagchi and Mukerjee 1983; Biswas 1987; Jha 2005). The region bears the imprints of Late Pleistocene ferruginous formations and the remnants of tropical deciduous forest. The catchment is characterised by dry, mild, sub-humid and subtropical monsoonal type climate and rainfall varies with elevation between 829 and $1907 \mathrm{~mm}$ between the period 1980 and 2015. During south-west monsoon (June to September) advective rainfall yields more than $80 \%$ out of the total annual average rainfall. Presence of laterites indicates the former existence of tropical wet dry periods (Tertiary) in this area. Hard massive Basalt of Jurassic to Cretaceous age, soft and medium hard laterites of Cenozoic age and China Clay of Late Pleistocene to Early Eocene age are also found in different parts of the basin in different depths and deep percolation is negligible (Saha 1961). The area covered mostly with the reddish, loose and friable sterile soil with ferruginous concretion called laterite soil (local name 'kankara'). Strong infertility of land is named it 'Rarh' or 'sterile land' (O'Malley 1914). The soil catenas consist of plateau fringe and high plain with Laterite Soil (Ultisols), adjacent slopes with sandy and loamy soils and small valley floors with older alluvial soils (Ulfisols). Moderate-maximum chemical weathering, moderate physical weathering, moderate mass wasting, moderatemaximum fluvial processes (sheet wash, rain splash, rill and gully erosion), laterisation, etc., are some major pedogeomorphic processes. Rolling lateritic uplands, wide planation surface, deep red weathering zone, duricrust of Feoxides (Ferrucrete), badlands in the upper part and low lying flat land in the lower part of the basin characterize the morphological features. Agricultural land use dominates 
the region $(>53 \%)$ while permanent forest cover constitutes only about $16 \%$ which lies exclusively in the lateritic upper catchment area and is decaying both qualitatively and quantitatively at very fast rate.

\section{Data collection protocols/methodology}

The BANCS model has been put forwarded and developed by Rosgen (1996, 2001, 2006, 2008a, b). Based on erosion variables and energy dispersal within the stream systems, BEHI and NBS ratings have used in the BANCS model in order to quantitatively evaluate stream bank erosion rates, for two hydo-physiographic regions. As per Rosgen (2001) streams found in metamorphic and/or sedimentary geologic regions are applicable to the Colorado dataset and those found in volcanism and/or alpine glaciations geologic regions are applicable to the Yellowstone National Park dataset. However, particular erosion rates provided by these studies may not be applicable with all alluvial streams (Rosgen 2008b). In the present case Bakreshwar River dataset have applied to the BANCS framework for determining bank erosion potential and rate.

\section{Pre field investigation methods: reach break detection and choice of the sample segment for study}

A given stream as identified by a name (e.g., Ganges, Mayurakshi) is not usually a single entry with uniform channel and flow characteristics over its entire length. Thus for describing and understanding stream bank erosion of the river Bakreshwar, we have focussed on the stream reach. A stream reach is a segment with fairly uniform size and shape, water surface slope, channel materials and flow characteristics (Dingman 2009). For the present study primarily two broad reach namely, non-perennial and perennial have identified. Further, reach breaks have then determined based on merging of the significant tributaries (NEH 1988). Apart from these, in recognition of the longitudinal differences prevail along the river, additional hydro-geomorphic variables such as underlying geology, stream confinement (or valley width), stage of channel evolution, dominant channel materials, major human intervention, etc., are some major determining variables (Montgomery and Buffington 1997; Harmar and Clifford 2007; Paz and Collischonn 2007; Rosgen 1998) have also considered. The entire present river stretch from source to outlet has been divided into seven total reaches (Fig. 1). At least two sample segments (Table 1) from each reach has then preferred for study for further investigation of the bank erosion taking place in that segment. Additionally, we have decided to take at least three cross-sections from each sample segment to meet the needs of present investigation. Altogether, 7 reaches, 24 reach segments and 78 cross-sections have been investigated along Bakreshwar River in this aim.

\section{Field methods}

BEHI and NBS are two quantitative tools have used here to estimate bank erosion status and potential. All data have been recorded on specified sheets during the field with reasonable accuracy.

\section{Bank erosion hazard index (BEHI)}

Rosgen (2006) have described BEHI as a fluvial geomorphic tool to evaluate the susceptibility of stream bank erosion on a section of a stream, based on a combination of some erodibility variables (e.g., top of bank, bankfull height, rooting depth, root density, bank angle, percent bank protection, bank composition, bank material stratification). The complete BEHI procedure consists of seven metrics; four observational (root depth, root density, bank angle, surface protection), one measurement based (bank height/bankfull height ratio) and two adjustment factors (i.e., bank material adjustment and stratification adjustment). See Rosgen (2001, 2006) for detailed description of each variable and rationale for BEHI rating values. Rosgen's (2001) BEHI assessment has assigned a numerical value which corresponds to an overall BEHI rating for a particular stream bank. In the present study BEHI table given by Rathbun (2004) modified from Rosgen (2001) have been consulted where metric scores have modified from a range of values to a single value to reduce subjectivity. As per the guidelines of Rathbun (2004) BEHI scores have been calculated for each sample segment individually for each bank (facing downstream). Data have been improved by incorporating the dataset collected by two independent assessment teams and the mean score has taken as standard.

\section{Near bank stress (NBS)}

Determination and evaluation of near bank stress of natural channels is essential for addressing a variety of problems in fluvial geomorphology and stream restoration (Kean 2003). Recently, a series of methods have been developed with the goal of addressing those problems. In the present section for NBS rating, work sheet provided by Rosgen (2006) have been consulted and the stress rating has predicted in level III. To maintain consistency, the ratio of near bank maximum depth to the bankfull mean depth (method 


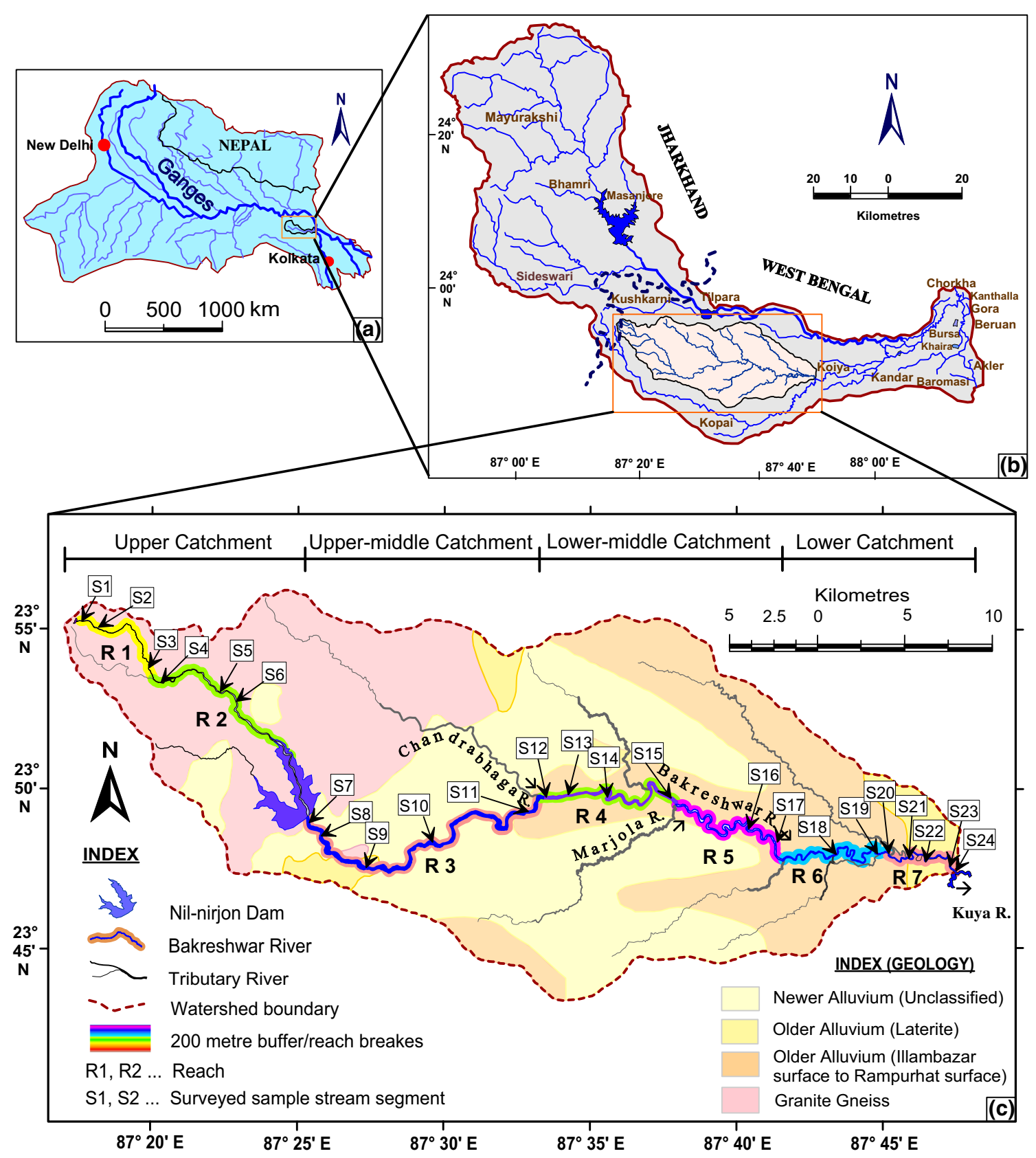

Fig. 1 Location map of a The Ganga Catchment, $\mathbf{b}$ the Mayurakshi River Basin and $\mathbf{c}$ the Bakreshwar River basin. Note, the delineated Bakreshwar river reaches have shown in different colour and

number 5) has been used for determining the NBS. Detailed methods of variable selection and rationale for NBS rating has been described by Rosgen (2006) that have been consulted rigorously. To avoid errors in bankfull determination cross sections have been taken at each assessed bank along a riffle and a pool. The data have then entered into worksheet for each survey stream segment. The ratio obtained has then conformed many times during the subsequent survey (Fig. 2). surveyed sample segments have labelled with their respective IDs. The spatial geology shown in the map is based on the Geological Quadrangle Map (73M) of Geological Survey of India

\section{Cross section procedures}

Cross sectional surveys have done to quantify the channel morphological attributes. At least three cross sections from each of the sample segment have taken among which at least one is along a riffle on that segment. In order to document erosion rates, toe pins have been installed and pre and post seasonal high discharge surveys have been compared to determine bank retreat. 


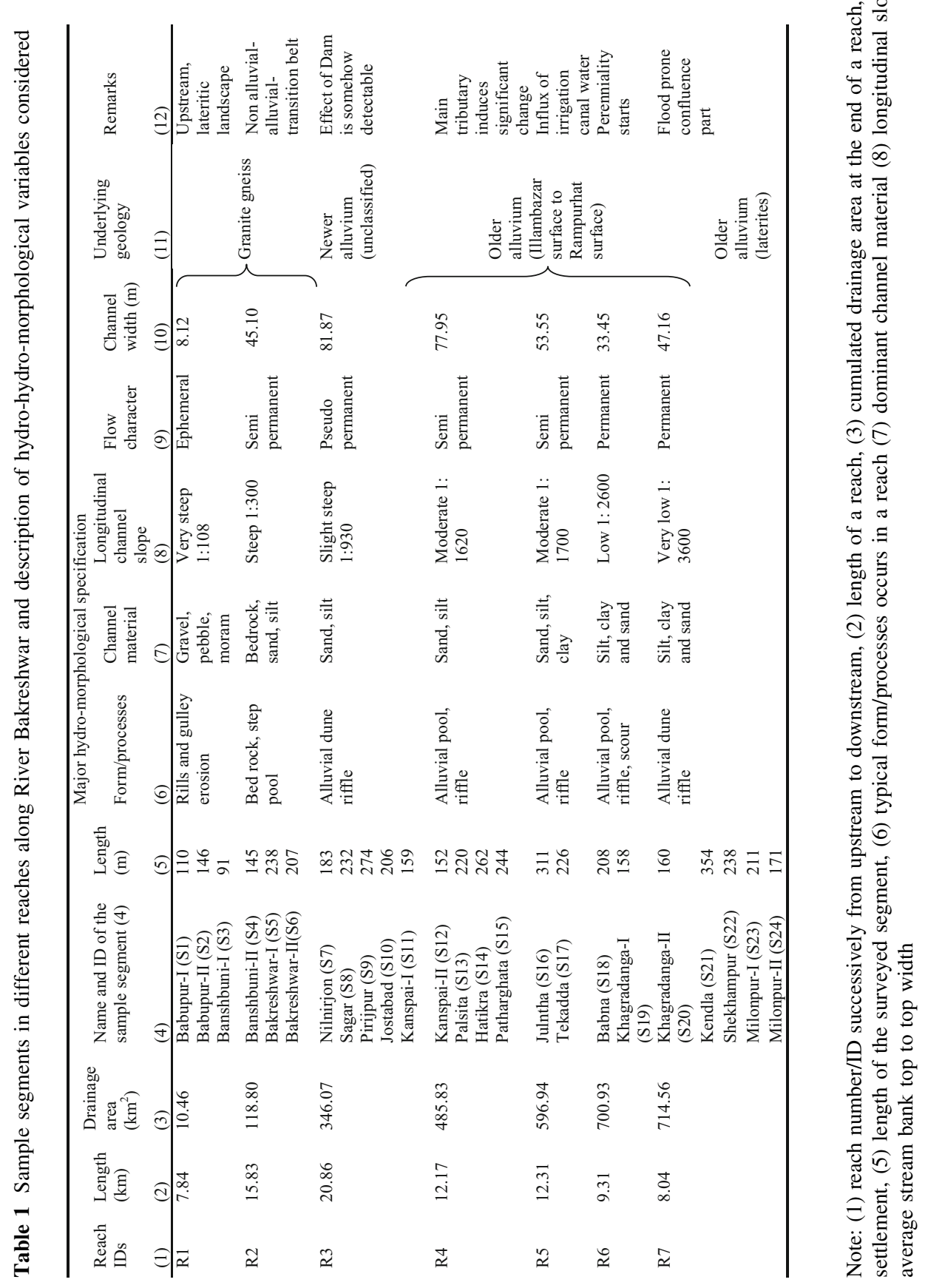




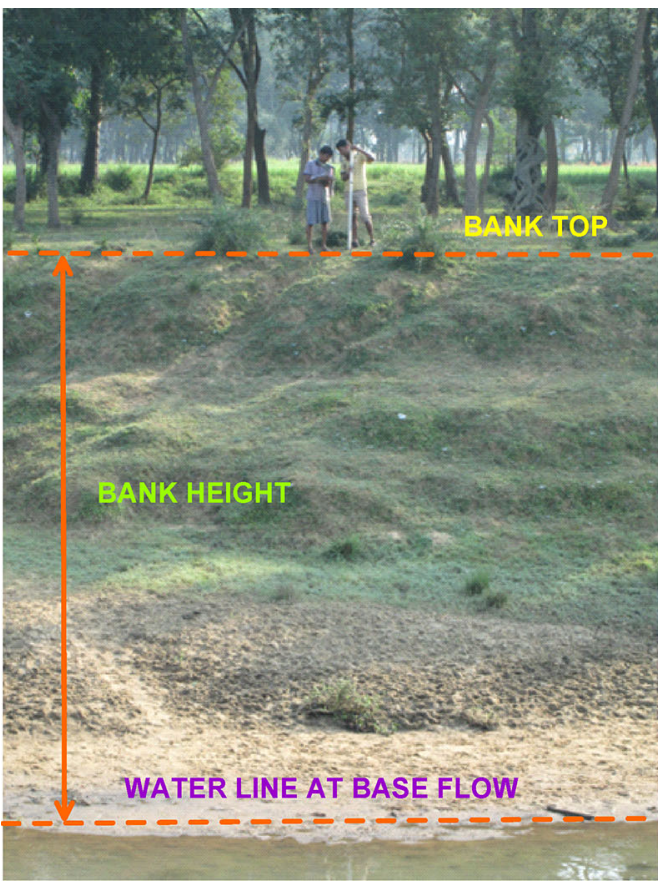

\section{MEASUREMENTS OF BEHI PRTICULARS FROM FIELD}
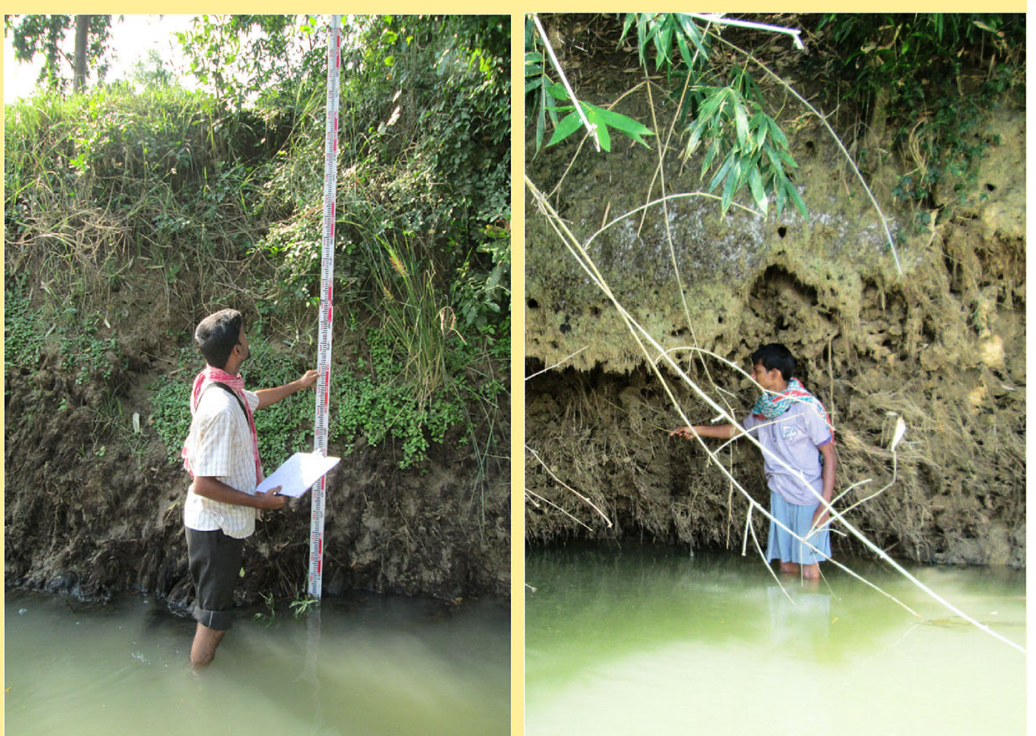

Fig. 2 Measurements of BEHI and NBS particulars in field by the authors and their associates during November 2010 and 2015

\section{Post field analytical methods-BEHI-NBS calibration}

The rates of observed bank erosion have been measured in response to the distance of bank recession per year. Mean (i.e., average of both the bank) BEHI, NBS, study bank height and length have been used to calculate the sum of eroded material in each segment. The location specific erosion rate is then compared to both BEHI and NBS ratings. Bank erosion amount (in tons/metre/year) have also been estimated based on BEHI and NBS matrix calibration table (adapted from: Upper Watts Branch Community Presentation 2012). Various computer programs have been used during the data processing and analyze phases. Arc GIS 10.0 (Environmental Systems Research Institute, Redlands, California) and Microsoft Office Excel (2010) have been utilized to compute and convey spatial and quantitative data sets.

\section{Tabulation, mapping and interpretation}

\section{Site specific stream statistics}

Each sample segment has been assessed using Rosgen's level II protocol (Rosgen 1994). Cross-sections at pool and riffle facets, sinuosity measurements, width/depth ratio, entrenchment ratio, bankfull cross sectional area, etc., geomorphic stream variables and morphological descriptions have considered using field data (Table 2).

\section{Bank erosion hazard assessment}

To calculate the BEHI 1st step is the measurement of all matrices for those sample segments considering both banks (total 48 bank segment) independently. Draft sheets for recording observations for BEHI has been made for each of the assessed stretch of the river. The BEHI score for the individual sections (for both banks) has been calculated by averaging the final scores of the cross-sections taken within each segment. Number of sample segment under the individual BEHI metrics corresponding to an erosion hazard category have also been calculated to assess the overall status of the river (Fig. 3).

Bank height is the vertical distance from the water line at base flow to the top of a bank. Bank full height is the maximum vertical height from thalweg to the water level at bank full. The values of bank height/bankfull height (Fig. 3a) are very high in most of the bank segments particularly in the lower middle and lower catchments of the river because the water levels rise significantly during peak monsoon season in these counterparts. In case of root density (i.e., the proportion of the stream bank surface covered and protected by plant roots) (Fig. 3b) most of the sample bank segments (total 18) cover only 15-29\% of which 11 has found at right bank. Maximum (80-100\%) and minimum $(<5 \%)$ root cover is found in Patharghata (R4, S15) and Hatikra (R4, S14), respectively. In case of bank angle (i.e., the angle of the 'lower bank' - the bank from the waterline at base flow to the top of the bank) 
Table 2 Sample segment/location specific hydro-geomorphic minutiae of Bakreshwar River

\begin{tabular}{|c|c|c|c|c|c|c|c|}
\hline Segments ID & $\begin{array}{l}\text { Bankfull } \\
\text { area }\left(\mathrm{m}^{2}\right)\end{array}$ & $\begin{array}{l}\text { Entrenchment } \\
\text { ratio }\end{array}$ & $\begin{array}{l}\text { Width/depth } \\
\text { ratio }\end{array}$ & Sinuosity & $\begin{array}{l}\text { Water surface } \\
\text { slope }\end{array}$ & $\begin{array}{l}\text { Seasonal water } \\
\text { level fluctuation } \\
\text { (in } \mathrm{m} \text { ) }\end{array}$ & $\begin{array}{l}\text { Rate of widening } \\
\text { (m/year) }\end{array}$ \\
\hline S1 & 9.59 & 1.16 & 5.177 & 1.21 & 0.83 & 0.32 & 0.55 \\
\hline $\mathrm{S} 2$ & 13.40 & 1.35 & 4.776 & 1.21 & 0.89 & 0.46 & 0.58 \\
\hline S3 & 11.79 & 2.6 & 5.222 & 1.35 & 0.29 & 0.79 & 0.31 \\
\hline S4 & 16.20 & 2.85 & 17.22 & 1.25 & 0.29 & 0.67 & 0.31 \\
\hline S5 & 97 & 2.11 & 26.3 & 1.3 & 0.089 & 0.89 & 0.24 \\
\hline S6 & 208 & 2.18 & 15.62 & 1.25 & 0.034 & 0.95 & 0.27 \\
\hline S7 & 247 & 1.29 & 15.61 & 1.14 & 0.062 & 0.79 & 0.01 \\
\hline S8 & 160 & 1.48 & 28.75 & 1.12 & 0.51 & 1.20 & 0.46 \\
\hline S9 & 219.29 & 1.35 & 52.06 & 1.21 & 0.038 & 0.99 & 0.34 \\
\hline $\mathrm{S} 10$ & 172.60 & 1.58 & 30.03 & 1.32 & 0.066 & 0.85 & 0.37 \\
\hline S11 & 102 & 1.43 & 83.7 & 1.44 & 0.052 & 0.86 & 0.43 \\
\hline $\mathrm{S} 12$ & 141.17 & 1.81 & 44.49 & 1.44 & 0.051 & 1.20 & 0.61 \\
\hline S13 & 203 & 1.23 & 33.28 & 1.35 & 0.033 & 0.99 & 0.31 \\
\hline S14 & 198 & 4.66 & 17.23 & 1.58 & 0.017 & 0.99 & 0.95 \\
\hline S15 & 177 & 2.1 & 41.01 & 1.32 & 0.029 & 1.50 & 0.31 \\
\hline S16 & 108 & 2.19 & 17.47 & 1.3 & 0.028 & 1.94 & 0.36 \\
\hline S17 & 128 & 2.89 & 25.21 & 1.25 & 0.039 & 1.53 & 1.07 \\
\hline S18 & 131 & 2.91 & 11.37 & 1.5 & 0.017 & 2.17 & 0.46 \\
\hline S19 & 79 & 3.21 & 9.16 & 1.4 & 0.015 & 2.11 & 0.30 \\
\hline S20 & 127.9 & 3.21 & 11.77 & 1.4 & 0.011 & 2.0 & 0.31 \\
\hline S21 & 128.2 & 3.18 & 11.12 & 1.39 & 0.026 & 2.5 & 0.85 \\
\hline $\mathrm{S} 22$ & 256 & 3.25 & 11.69 & 1.56 & 0.028 & 1.89 & 1.07 \\
\hline $\mathrm{S} 23$ & 194 & 4.53 & 11.63 & 1.51 & 0.015 & 2.5 & 0.34 \\
\hline S24 & 210 & 4.62 & 11.41 & 1.51 & 0.01 & 2.85 & 0.52 \\
\hline
\end{tabular}

(Fig. 3c) it is found that most of the sample bank segments (total 21) are having angle between $61^{\circ}$ and $80^{\circ}$. Only three sample bank segments along the left bank and one along the right bank possess overhanging angle $\left(81^{\circ}-90^{\circ}\right)$. Moreover, 26 sample bank segments is having the surface protection 30-54 \% (Fig. 3d) and in 15 sample bank segments the surface protection is only $15-29 \%$. It has also being noticed that in most of the cases root depth and density and surface protection is less where as bank angle is high specially in the left bank segments.

Based on the variables considered BEHI scores for the individual sample segments have been calculated for both the banks and plotted it on Fig. 4.

Results (Figs. 4 and 5) show that Babupur-I (R1, S1) and Babupur-II (R1, S2) are highly susceptible to erosion as these segments are prone to lateritic gully erosion. Left bank of Hatikra (R4, S14) and Kanspai-II (R4, S12) are also identified in this category. The value of BEHI decreases marginally downstream $(y=-0.399 x+35.65)$. It means the erosion rate as well as probability of channel modification decreases downstream. Factors those are responsible for high stream bank erosion hazard potential in the upper catchment area are friable lateritic bank material, less woody vegetation cover, etc. On the transition between lower and middle catchment of Bakreshwar, the presence of bank vegetation, active sedimentation, stable meandering channel, a wide channel with braided reaches and clayey bank materials resist the bank erosion. Near the confluence segment stream bank erosion hazard potential is quite more because of barren bank, steep slope of bank, finer bank materials and left ward migration tendency of the thalweg line. From source to mouth it is also noticed that the rate of erosion is not same on both the banks of the assessed river. Figure 3 clearly shows the fact that in most of the sample segments the rate of bank erosion is slightly more on left bank of the river.

\section{Near bank stress assessment}

NBS signifies potential disproportionate energy distribution in the near bank region (Rosgen 1996, 2001, 2006, 2008a, b). Changes in near bank stress can accelerate stream bank erosion (Rosgen 2001). For the present assessment criteria noted in subsection 3.2.2 have been 

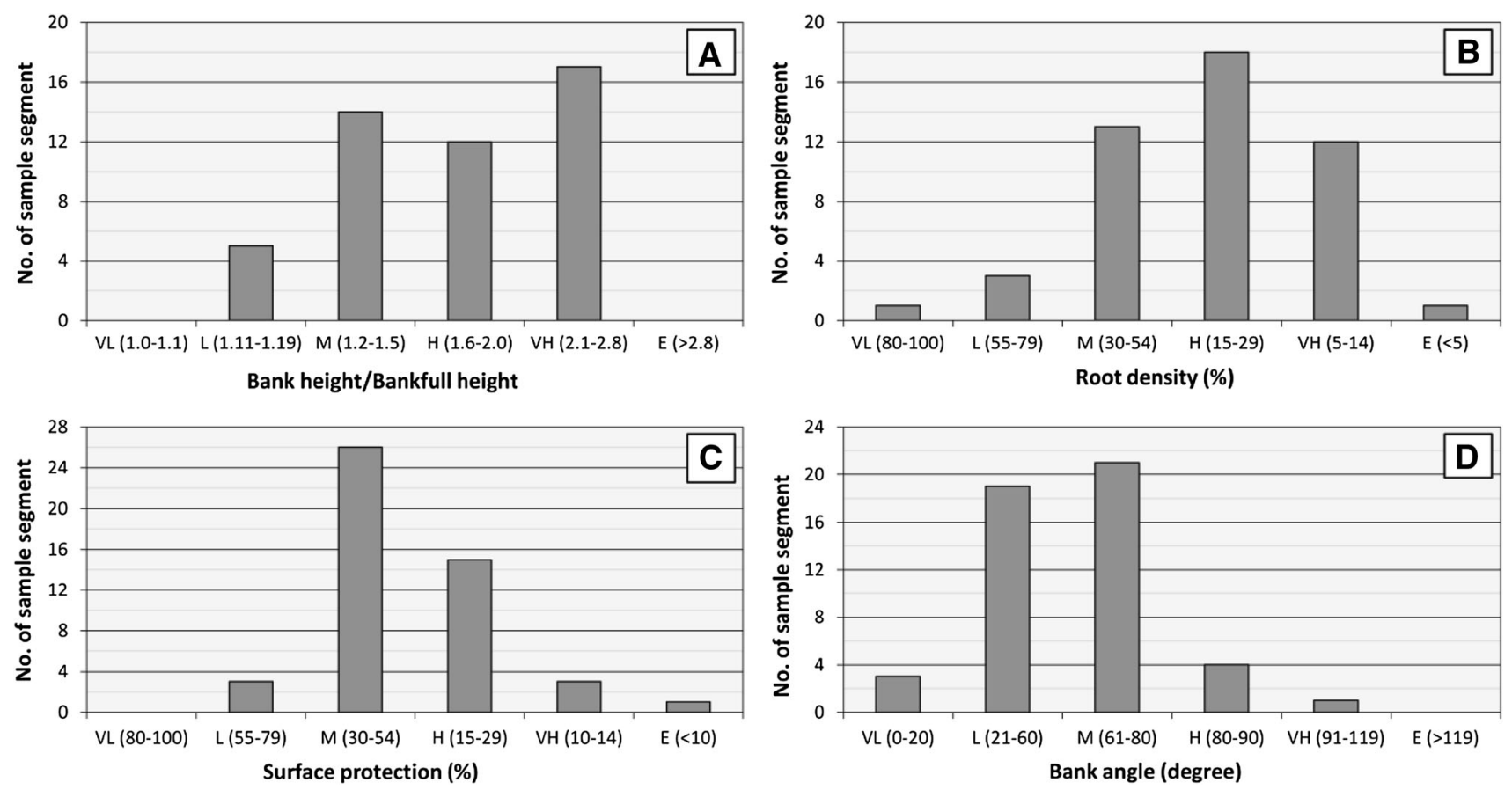

Fig. 3 Bar graphs of four different BEHI parameters (a bank height/bankfull height; b root cover, c surface protection, d bank angle). Note: the abbreviations VL, L, M, H, VH and E stand for BEHI ratings category very low, low, moderate, high, very high and extreme, respectively

Fig. 4 The BEHI scores for individual bank segments for all the selected sample locations along the River Bakreshwar

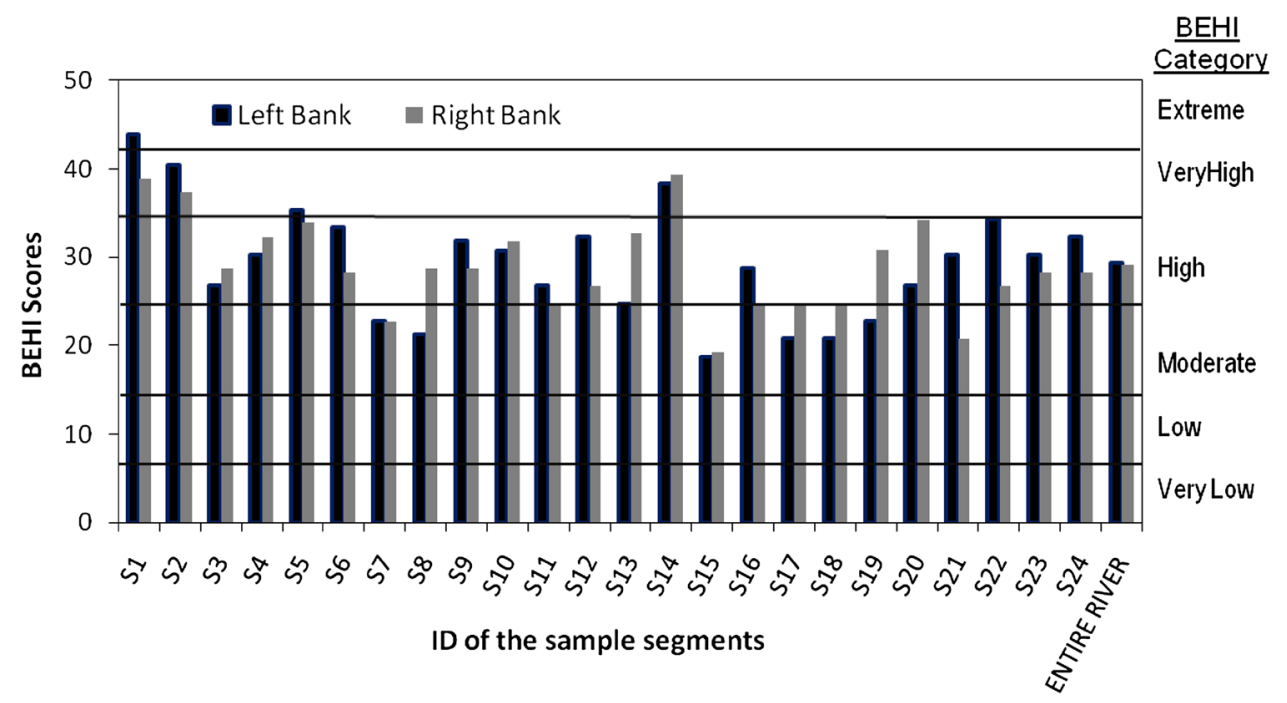

recognized to assist in the field determination and record the final NBS rating for the reference segments (Table 3; Fig. 6).

\section{BEHI and NBS relation and estimation of bank erosion}

The BEHI and NBS values of all 48 individual sample bank segment have been plotted on Fig. 7 from which it is found that 26 banks segments posses High BEHI ratings. 15 bank segments posses Moderate BEHI ratings. But there is no bank segment under low and very low BEHI category. The NBS values among the 48 sample bank segments 17 posses Moderate NBS value followed by 16 bank segments under low NBS category. The average bank erosion hazard for the whole river is high to moderate and near bank stress is moderate to low.

The BEHI and NBS risk ratings have used to develop the relations shown in Fig. 8a (for left bank of Bakreshwar River data) and in Fig. 8b (for right bank of Bakreshwar River data). Applications of these relations allow a statistically valid means of predicting stream bank erosion as predicted by 
Fig. 5 Segment (location) specific mean BEHI ratings along river Bakreshwar. Outline (grey line) represents a buffered zone surrounding the entire length of Bakreshwar River (black/blue line), coloured circles represent BEHI scores for the individual sample segments

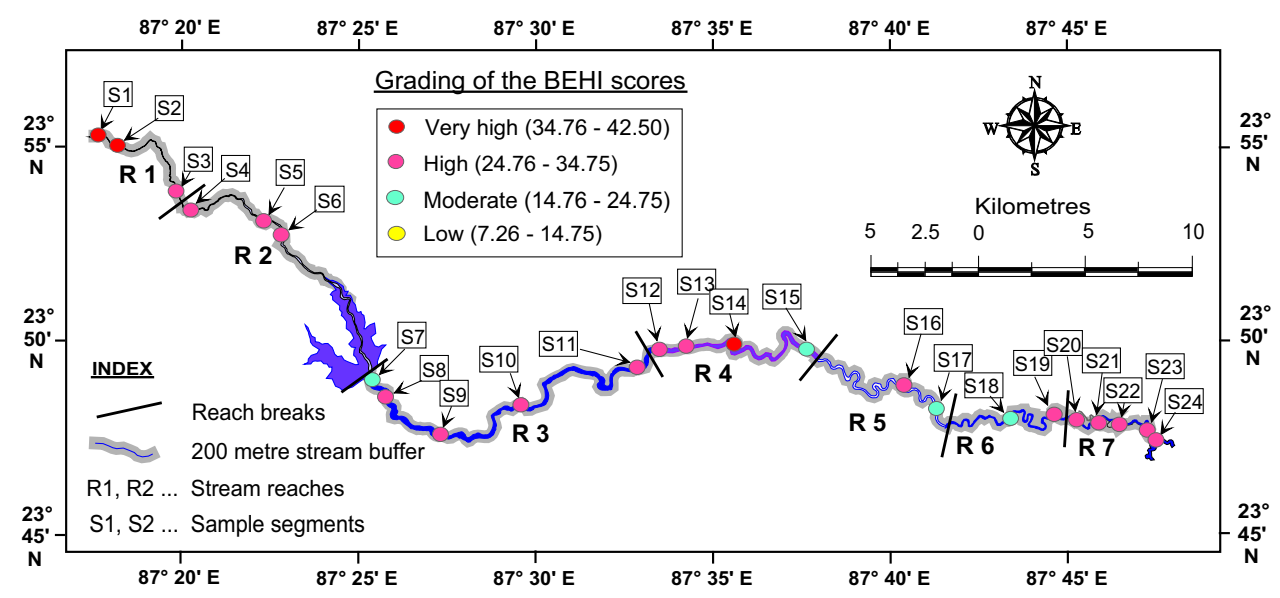

Table 3 NBS results of the sample segments along Bakreshwar River

\begin{tabular}{|c|c|c|c|c|c|c|c|c|c|c|}
\hline \multirow{2}{*}{$\begin{array}{l}\text { Sample } \\
\text { segments ID }\end{array}$} & \multicolumn{4}{|l|}{ Left bank } & \multicolumn{4}{|l|}{ Right bank } & \multirow{2}{*}{$\begin{array}{l}\text { Mean } \\
\text { scores }\end{array}$} & \multirow{2}{*}{$\begin{array}{l}\text { Average } \\
\text { ratings }\end{array}$} \\
\hline & $\begin{array}{l}\text { Near bank max. } \\
\text { depth }(m)\end{array}$ & $\begin{array}{l}\text { Bankfull mean } \\
\text { depth }(m)\end{array}$ & Ratio & $\begin{array}{l}\text { NBS } \\
\text { rating }\end{array}$ & $\begin{array}{l}\text { Near bank max. } \\
\text { depth }(m)\end{array}$ & $\begin{array}{l}\text { Bankfull mean } \\
\text { depth }(\mathrm{m})\end{array}$ & Ratio & $\begin{array}{l}\text { NBS } \\
\text { ratings }\end{array}$ & & \\
\hline S1 & 2.39 & 1.36 & 1.76 & M & 2.59 & 1.36 & 1.91 & $\mathrm{H}$ & 1.84 & $\mathrm{H}$ \\
\hline $\mathrm{S} 2$ & 2.49 & 1.28 & 1.95 & $\mathrm{H}$ & 2.2 & 1.28 & 1.72 & M & 1.84 & $\mathrm{H}$ \\
\hline S3 & 1.17 & 0.77 & 1.52 & M & 1.49 & 0.77 & 1.94 & $\mathrm{H}$ & 1.73 & M \\
\hline S4 & 1.02 & 0.87 & 1.17 & $\mathrm{~L}$ & 1.7 & 0.87 & 1.95 & $\mathrm{H}$ & 1.56 & M \\
\hline S5 & 1.55 & 1.52 & 1.02 & $\mathrm{~L}$ & 2.7 & 1.52 & 1.78 & M & 1.4 & $\mathrm{~L}$ \\
\hline S6 & 4.72 & 3.05 & 1.54 & M & 5.3 & 3.05 & 1.74 & M & 1.64 & M \\
\hline S7 & 3.96 & 3.17 & 1.24 & $\mathrm{~L}$ & 3.59 & 3.17 & 1.13 & $\mathrm{~L}$ & 1.19 & $\mathrm{~L}$ \\
\hline S8 & 1.65 & 1.66 & 0.99 & $\mathrm{~L}$ & 1.39 & 1.66 & 0.84 & VL & 0.92 & VL \\
\hline S9 & 1.8 & 1.55 & 1.16 & $\mathrm{~L}$ & 2.7 & 1.55 & 1.74 & M & 1.45 & $\mathrm{~L}$ \\
\hline S10 & 2.15 & 1.49 & 1.44 & $\mathrm{~L}$ & 2.8 & 1.49 & 1.88 & $\mathrm{H}$ & 1.66 & M \\
\hline S11 & 1.32 & 1.1 & 1.2 & $\mathrm{~L}$ & 1.54 & 1.1 & 1.4 & $\mathrm{~L}$ & 1.3 & $\mathrm{~L}$ \\
\hline $\mathrm{S} 12$ & 2.85 & 1.48 & 1.93 & $\mathrm{H}$ & 2.75 & 1.48 & 1.86 & $\mathrm{H}$ & 1.89 & $\mathrm{H}$ \\
\hline S13 & 2.85 & 1.67 & 1.71 & M & 3.03 & 1.67 & 1.81 & $\mathrm{H}$ & 1.76 & M \\
\hline S14 & 5.67 & 2.49 & 2.28 & $\mathrm{H}$ & 5.76 & 2.49 & 2.31 & $\mathrm{H}$ & 2.29 & $\mathrm{H}$ \\
\hline S15 & 1.3 & 1.98 & 0.66 & VL & 3.9 & 1.98 & 1.96 & $\mathrm{H}$ & 1.31 & $\mathrm{~L}$ \\
\hline S16 & 3.29 & 2.19 & 1.51 & M & 2.45 & 2.19 & 1.12 & $\mathrm{~L}$ & 1.31 & $\mathrm{~L}$ \\
\hline S17 & 2.99 & 1.75 & 1.71 & M & 3.11 & 1.75 & 1.77 & M & 1.74 & M \\
\hline S18 & 3.54 & 2.79 & 1.27 & $\mathrm{~L}$ & 4.48 & 2.79 & 1.61 & M & 1.44 & $\mathrm{~L}$ \\
\hline S19 & 3.81 & 2.94 & 1.3 & $\mathrm{~L}$ & 4.11 & 2.94 & 1.39 & $\mathrm{~L}$ & 1.35 & $\mathrm{~L}$ \\
\hline S20 & 5.15 & 2.89 & 1.78 & M & 4.21 & 2.89 & 1.45 & $\mathrm{~L}$ & 1.62 & M \\
\hline S21 & 4.75 & 3.08 & 1.53 & M & 4.39 & 3.08 & 1.42 & $\mathrm{~L}$ & 1.48 & $\mathrm{~L}$ \\
\hline S22 & 5.64 & 3.69 & 1.53 & M & 5.55 & 3.69 & 1.51 & M & 1.52 & M \\
\hline $\mathrm{S} 23$ & 4.85 & 3.17 & 1.53 & M & 5.76 & 3.17 & 1.81 & $\mathrm{H}$ & 1.67 & M \\
\hline S24 & 6.46 & 3.5 & 1.83 & $\mathrm{H}$ & 4.94 & 3.51 & 1.41 & $\mathrm{~L}$ & 1.62 & M \\
\hline $\begin{array}{l}\text { Average of } \\
\text { the river }\end{array}$ & 3.23 & 2.15 & 1.5 & M & 3.44 & 2.15 & 1.6 & M & 1.56 & M \\
\hline
\end{tabular}

Rosgen (1996, 2001, 2006, 2008a, b). Furthermore, the relations permit obtaining BEHI and NBS ratings along river reaches of varying condition. The relations may not be valid universally over the entire lateritic alluvium river, but can be applied in the lateritic Rarh Bengal where uniform conditions are existing. BEHI and NBS ratings have also been plotted separately against observed bank erosion rate to validate the methods in these conditions (Figs. 9, 10). 
Fig. 6 Segment (location) specific mean NBS ratings along river Bakreshwar. Outline (grey line) represents a buffer zone surrounding the entire length of Bakreshwar River (black/blue line), colour circles represent NBS scores for the individual sample locations
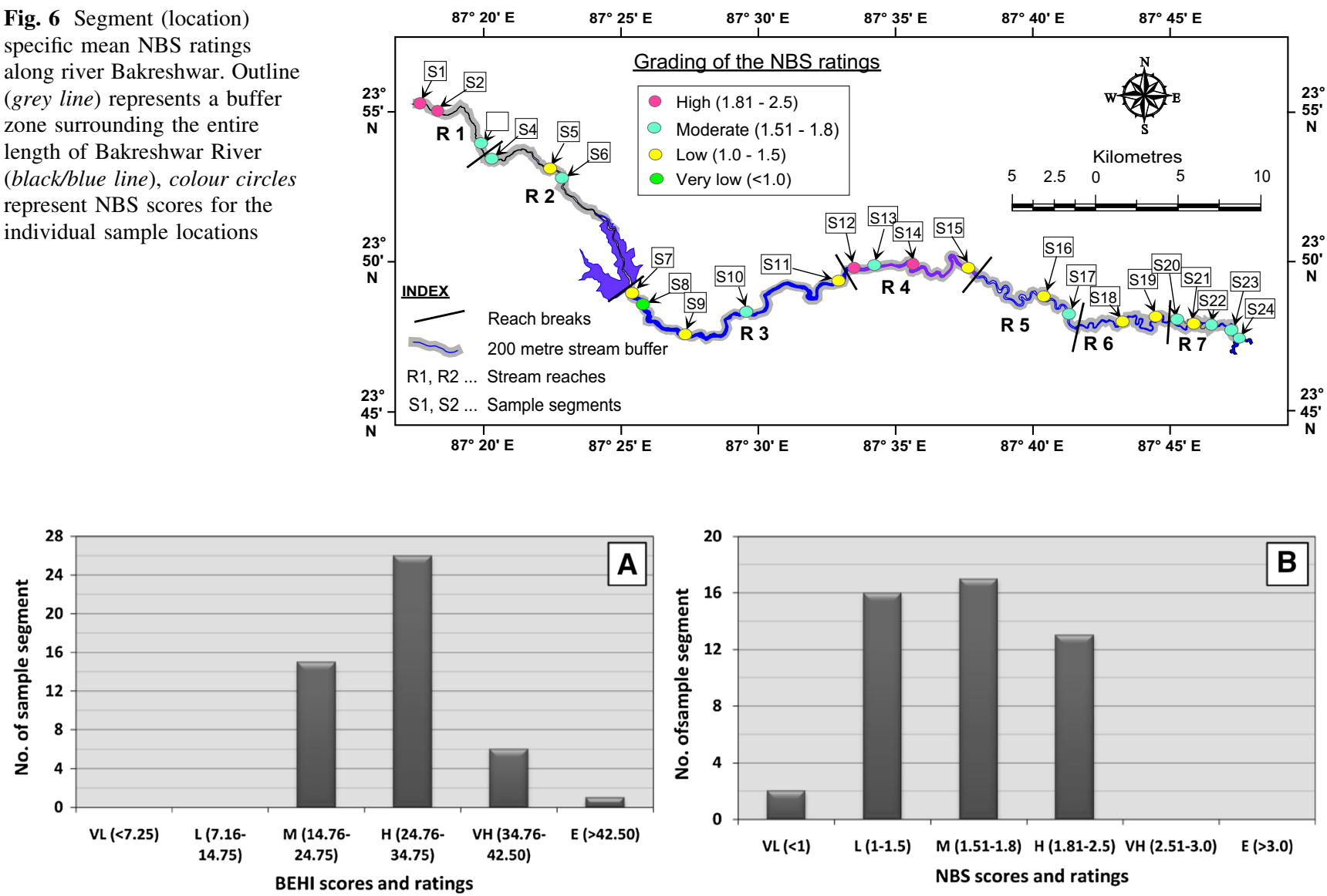

Fig. 7 Bar graphs showing numbers of sample bank segments are under different BEHI and NBS classes. Note: the abbreviations VL, L, M, H, $\mathrm{VH}$ and $\mathrm{E}$ stands for BEHI and NBS ratings category very low, low, moderate, high, very high and extreme, respectively
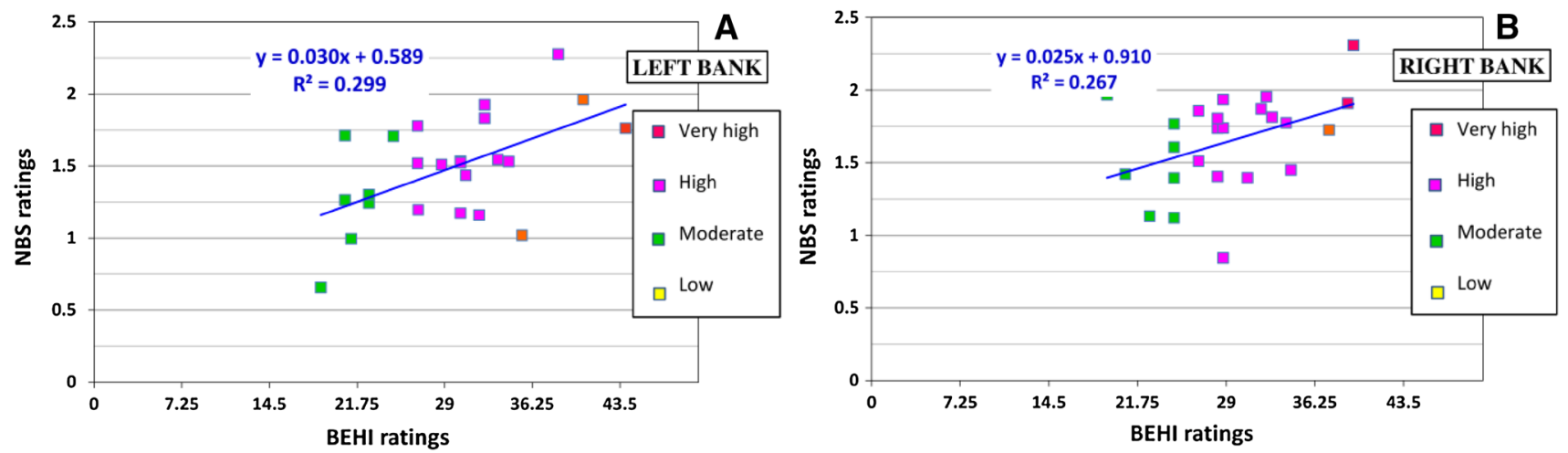

Fig. 8 The BEHI and NBS ratings are co-ordinated separately for each sample bank (a left bank; b right bank)

Plots of the observed bank erosion rates as a function of BEHI gave a positive relationship for high/very high erosion potential bank erosion monitoring sample segments, with an $\mathrm{R}^{2}$ of 0.213 (Fig. 9). Plots of the observed bank erosion rates as a function of NBS also gave a positive relationship for moderate/high erosion potential bank erosion monitoring segments, with an $\mathrm{R}^{2}$ of 0.278 (Fig. 10). These $\mathrm{R}^{2}$ values demonstrate a correlation between observed bank erosion and BEHI/NBS, but with a poor fit. Thus both BEHI and NBS may consider insignificant predictors of bank erosion rate irrespective of prediction from the graphical plotting as done above. Therefore, we can conclude that Bakreshwar River does not produce a satisfactory predictive curve to estimate bank erosion rates in regard to their BEHI and NBS ratings. Further inspection of our data reveals the reason for their insignificance. High 
Fig. 9 BEHI ratings for all sample segments have been plotted against observed bank erosion rate on a semi-log graph

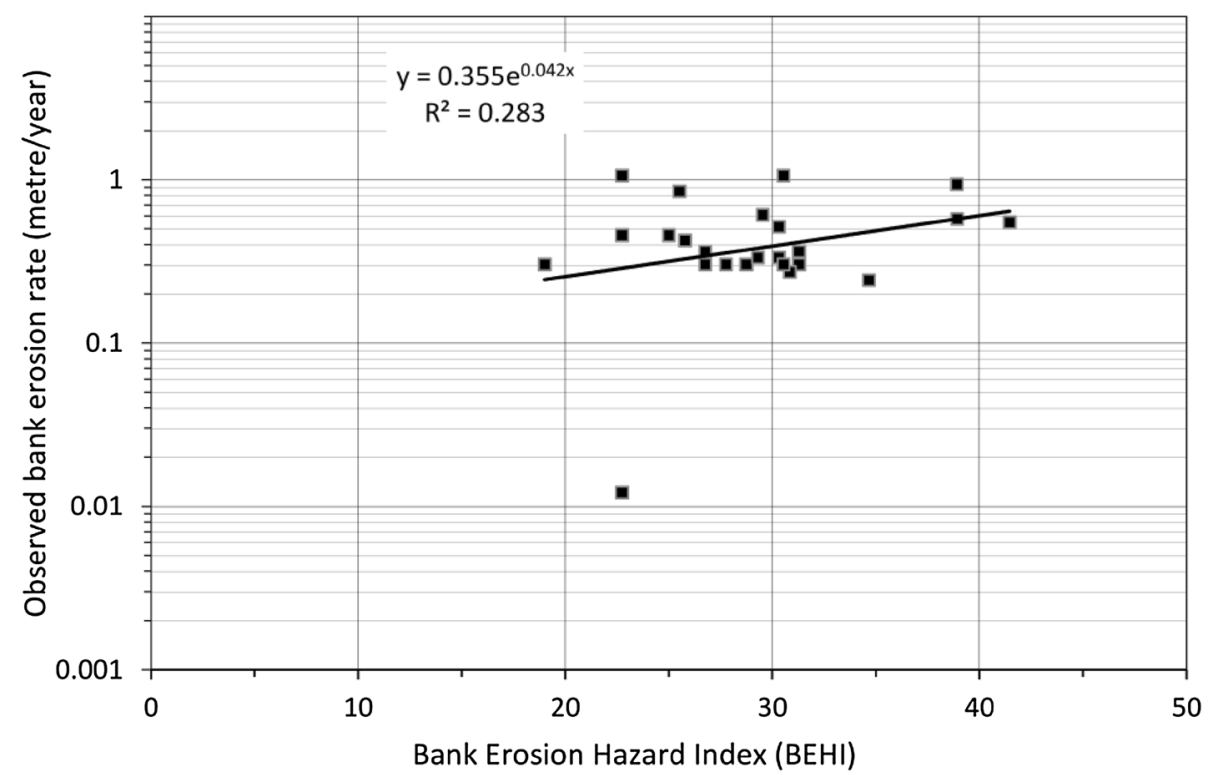

Fig. 10 NBS ratings for all sample segments have been plotted against observed bank erosion rates on a semi-log graph

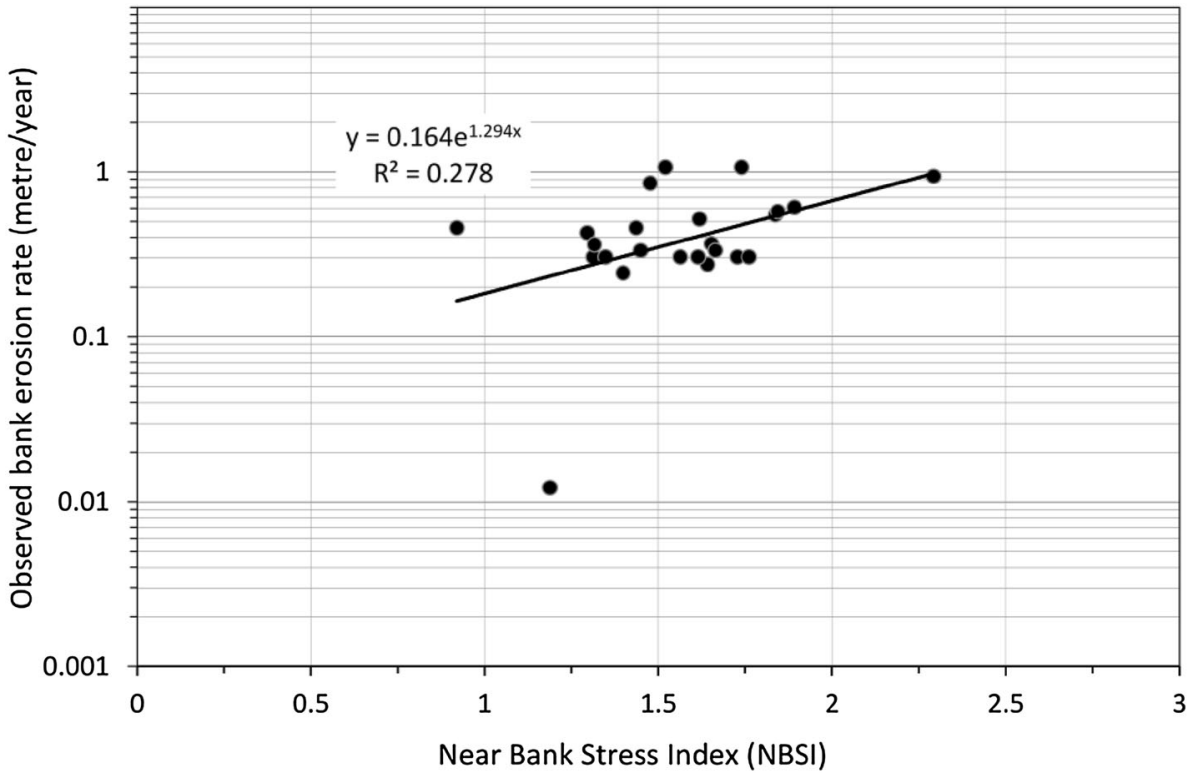

seasonal water level fluctuation causes heavy erosion in the loose and friable lateritic soil dominant banks in this river.

The volume of eroded material from bank has also been estimated based on BEHI and NBS matrix calibration (vide Upper Watts Branch Community Presentation 2012) and field measurements. The corresponding observed and predicted erosion rate have been forwarded in Table 4.

\section{Sample segment specific investigation of bank erosion}

Erosion processes may differ significantly in stream reaches possessing certain geomorphic characteristics.
Observed erosion rates (Table 4) in sample segments S14, $\mathrm{S} 17, \mathrm{~S} 18, \mathrm{~S} 21$ to $\mathrm{S} 24$ have experienced high rate of erosion. Sample segment S14, S18, S22 to S24 are more sinuous $(>1.5)$ which can intensify hydraulic stress on the banks laterally. High erosion rates and corresponding BEHI ratings in $\mathrm{S} 17$ and $\mathrm{S} 21$ can also be explained by lack of riparian vegetation, coarser banks composition, influx of irrigated canal water and water from agricultural land especially during lean season etc. encourage high rate of erosion.

At the sample segments, most significant amount of erosion is measured at the downstream portions of the river. General observations indicate slumping of permeable 
Table 4 Observed and estimated erosion rates for all the sample locations/segments

\begin{tabular}{|c|c|c|c|c|c|c|c|c|c|c|}
\hline $\begin{array}{l}\text { Site } \\
\text { ID }\end{array}$ & $\begin{array}{l}\text { Station } \\
\text { distance } \\
\text { from the } \\
\text { source } \\
\text { (m) } \\
1\end{array}$ & $\begin{array}{l}\text { Mean } \\
\text { BEHI } \\
\text { (adjective) }\end{array}$ & $\begin{array}{l}\text { Mean } \\
\text { NBS } \\
\text { (adjective) }\end{array}$ & $\begin{array}{l}\text { Observed } \\
\text { bank } \\
\text { erosion } \\
\text { rate }(\mathrm{m} / \mathrm{y})\end{array}$ & $\begin{array}{l}\text { Length } \\
\text { of } \\
\text { assessed } \\
\text { bank }(\mathrm{m})\end{array}$ & $\begin{array}{l}\text { Bank } \\
\text { height } \\
(\mathrm{m})\end{array}$ & $\begin{array}{l}\text { Observed } \\
\text { erosion sub- } \\
\text { total }\left(\mathrm{m}^{3} / \mathrm{y}\right) \\
{[4 \times 5 \times 6]} \\
7\end{array}$ & $\begin{array}{l}\text { Total } \\
\text { erosion } \\
(\mathrm{t} / \mathrm{y}) \\
{[7 \times 1.7]} \\
8\end{array}$ & $\begin{array}{l}\text { Observed } \\
\text { erosion } \\
\text { rate }(\mathrm{t} / \mathrm{m} / \\
\text { y) }[8 / 5]\end{array}$ & $\begin{array}{l}\text { Estimated } \\
\text { erosion rate } \\
(\mathrm{t} / \mathrm{m} / \mathrm{y})\end{array}$ \\
\hline S1 & 974 & 41.45 & 1.84 & 0.55 & 110 & 1.31 & 79.26 & 134.73 & 1.225 & 3.62 \\
\hline S2 & 1037 & 38.925 & 1.84 & 0.58 & 146 & 1.45 & 122.79 & 208.74 & 1.429 & 3.62 \\
\hline S3 & 7684 & 27.75 & 1.73 & 0.3 & 91 & 0.78 & 21.29 & 36.19 & 0.398 & 0.54 \\
\hline S4 & 7729 & 31.3 & 1.56 & 0.3 & 145 & 0.93 & 40.46 & 68.77 & 0.474 & 0.54 \\
\hline S5 & 13,223 & 34.65 & 1.39 & 0.24 & 238 & 1.49 & 85.11 & 144.69 & 0.608 & 0.36 \\
\hline S6 & 13,474 & 30.85 & 1.64 & 0.27 & 207 & 2.65 & 148.11 & 251.78 & 1.216 & 0.54 \\
\hline S7 & 23,602 & 22.75 & 1.19 & 0.01 & 183 & 3.27 & 5.98 & 10.17 & 0.056 & 0.05 \\
\hline S8 & 24,164 & 25 & 0.92 & 0.46 & 232 & 1.39 & 148.34 & 252.18 & 1.087 & 0.36 \\
\hline S9 & 29,187 & 30.3 & 1.45 & 0.34 & 274 & 2.15 & 200.29 & 340.5 & 1.243 & 0.36 \\
\hline S10 & 34,374 & 31.3 & 1.65 & 0.37 & 206 & 2.22 & 169.21 & 287.65 & 1.397 & 0.54 \\
\hline S11 & 44,242 & 25.775 & 1.29 & 0.43 & 159 & 1.48 & 101.19 & 172.02 & 1.082 & 0.36 \\
\hline $\mathrm{S} 12$ & 44,372 & 29.525 & 1.89 & 0.61 & 152 & 1.85 & 171.53 & 291.60 & 1.918 & 0.72 \\
\hline S13 & 46,094 & 28.75 & 1.76 & 0.3 & 220 & 2.65 & 174.9 & 297.33 & 1.352 & 0.54 \\
\hline S14 & 49,499 & 38.9 & 2.29 & 0.94 & 262 & 3.2 & 788.1 & 1339.76 & 5.114 & 3.62 \\
\hline S15 & 55,246 & 19 & 1.31 & 0.3 & 244 & 2.25 & 164.7 & 279.99 & 1.148 & 0.54 \\
\hline S16 & 63,340 & 26.75 & 1.32 & 0.36 & 311 & 2.15 & 240.71 & 409.21 & 1.316 & 0.36 \\
\hline S17 & 67,716 & 22.75 & 1.74 & 1.07 & 226 & 2.39 & 577.95 & 982.52 & 4.347 & 0.14 \\
\hline S18 & 74,086 & 22.75 & 1.44 & 0.46 & 208 & 3.42 & 327.23 & 556.28 & 2.674 & 0.05 \\
\hline S19 & 77,674 & 26.75 & 1.35 & 0.3 & 158 & 3.51 & 166.37 & 282.84 & 1.790 & 0.36 \\
\hline S20 & 77,776 & 30.525 & 1.61 & 0.3 & 160 & 3.83 & 183.84 & 312.53 & 1.953 & 0.54 \\
\hline S21 & 81,078 & 25.525 & 1.48 & 0.85 & 354 & 3.25 & 977.93 & 1662.47 & 4.696 & 0.36 \\
\hline $\mathrm{S} 22$ & 83,058 & 30.525 & 1.52 & 1.07 & 238 & 3.39 & 863.3 & 1467.61 & 6.166 & 0.54 \\
\hline $\mathrm{S} 23$ & 86,358 & 29.3 & 1.66 & 0.34 & 211 & 4.11 & 294.85 & 501.25 & 2.376 & 0.54 \\
\hline S24 & 86,369 & 30.3 & 1.62 & 0.52 & 171 & 3.59 & 319.22 & 542.68 & 3.174 & 0.54 \\
\hline \multicolumn{7}{|c|}{$\begin{array}{l}\text { Conversion of erosion }\left(\mathrm{m}^{3} / \mathrm{y}\right) \text { to }(\mathrm{t} / \mathrm{y}) \text { [multiplying total erosion }\left(\mathrm{m}^{3} / \mathrm{year}\right) \text { by } \\
\text { 1.7] [Note: } 1 \mathrm{~m}^{3}=1.7 \text { tons for average material type] }\left(\sum \text { column } 8\right)\end{array}$} & \multicolumn{3}{|c|}{ Total erosion $=10833.505 \mathrm{t} / \mathrm{y}$} & \multirow[t]{4}{*}{$\begin{array}{l}\text { Average estimated } \\
\text { erosion } \\
\text { rate }=0.8317965939 \\
\mathrm{t} / \mathrm{m} / \mathrm{y}\end{array}$} \\
\hline \multicolumn{7}{|c|}{$\begin{array}{l}\text { Calculation of erosion per unit length of channel. [dividing total erosion } \\
\text { (tons/year) by total length of channel }(\mathrm{m}) \text { surveyed] ( } \sum \text { column } \\
8 / 4904.8416 \mathrm{~m})\end{array}$} & \multicolumn{3}{|c|}{ Total erosion $=2.2082155 \mathrm{t} / \mathrm{m} / \mathrm{y}$} & \\
\hline \multicolumn{7}{|c|}{ Average erosion [sum erosion sub-totals $\left(\sum\right.$ column-9)/24] } & \multicolumn{3}{|c|}{$\begin{array}{l}\text { Average annual erosion }=2.0099313 \\
\text { t/m/year }\end{array}$} & \\
\hline \multicolumn{7}{|c|}{$\begin{array}{l}\text { Total erosion of by the river in a year [multiplying avg. erosion by total length } \\
\text { of the river }(\mathrm{m}) \text { ] }\end{array}$} & \multicolumn{3}{|c|}{$\begin{array}{l}\text { Total river erosion volume in a } \\
\text { year }=173595.752 \mathrm{t} / \mathrm{y}\end{array}$} & \\
\hline
\end{tabular}

Note: calculation is based on example summary of Rosgen (2006) and US-EPA (2006) for estimating annual stream bank erosion. The abbreviation $\mathrm{m}, \mathrm{t}$ and $\mathrm{y}$ stands for metre, metric ton and year, respectively

sand within a clay matrix occurred during the peak flow events associated with storm rainfall in 2011, 2013 and 2015.

Increased erosion rate that have occurred in S12 is primarily due to meeting of main tributary Chandrabhaga that debouches sizeable water volume at this location. Sample segment S19 and S20 have associated with high erosion due to constricted flow.
Most of the sample segments in the upstream, erosion volume are comparatively low in spite of high to moderate BEHI and NBS rating. These segments have observed as relatively stable sections as they attributed the absence of any strong fluvial erosive action due to its non perenniality. Sample segment S7 just below the Nilnirjon Dam have concrete bank wall. At the other sample segments (S8, S9, S10, S11, S13, S15 and S16) less channel constrictions, 
relatively greater vegetation cover on bank etc. have lessened the erosion rate.

\section{Limitations for the validation of BANCS model}

As the present study evaluates the validation of BANCS model in river Bakreshwar of Eastern India, it is important to understand and state the limitations implicit in the model.

Higher NBS ratings often indicate a higher erosion rate along the bank and vice versa (Rosgen 2001, 2006), which has not observed in Table 4. For instance, the assessed bank segmrnts at the upstream sample locations (S1-S4) correspond with a high to moderate NBS rating but the observed erosion rate is quite low. In the sample segment S8, S9, S11, S15, S16, S18, S19, S21 regardless of having low NBS rating bank erosion is quite more. Actually, in these locations the thalweg follows median axis of the channel and hence little chance of high shear stress is on the banks. The particular method which is used, the ratio of maximum bankfull depth to mean bankfull depth, may be a better predictor for areas those are not steeply sloped or uniformly entrenched such as sample reach S14, S16, S19 to S24.

By comparing the BEHI-NBS calibration model with field generated erosion data, it is found that erosion rates are near similar in case of only four sample segments or $16.67 \%$ to total. In 13 sample segments or $45.17 \%$ to total the model based erosional rate is highly different from the observed erosion rate during the study period of 5 consecutive years. Hence BEHI-NBS matrix model is potentially not a sound erosion predictive model for our study area.

Actually for a given geology the rate of bank erosion varies substantially. For instance, Rosgen (2001) found that loess soils of the Mid-Western United States would yield much higher erosion rates for the same BEHI and NBS ratings than the curves presented for Lamar Basin in Yellowstone National Park, Montana and the Front Range of Colorado. Moreover, Bank erosion processes and rates are affected by many interconnected variables such as annual and seasonal precipitation rates, frequency and duration of storm events, soil moisture levels, vegetation type and density of root systems, land drainage, reservoir development and channelization projects (Sass 2011). Field work after flooding has potential user bias due to variables appearing more severe. BEHI ratings may be influenced by loss of vegetation, excessive aggradations and degradation, bank exposure, channel avulsions, mass failures, etc. (Markowitz and Newton 2011). Thus, it requires for field practitioners in the same line to establish the local curves fit for Rarh Bengal physiographic province based on extensive field survey. So much scope is still left to work on framing suitable predictive model(s).

\section{Conclusions}

In the present piece of writing an inventory of bank conditions of Bakreshwar River has been recorded and quantitative measurements of BEHI and NBS have been done. Concerning the BANCS model we have seen that BEHI-NBS calibration method is not significant predictors of bank erosion rate for the present river. Actually erosion related processes in varying boundary conditions of Rarh Bengal alluvial river differs significantly. These boundary conditions may influence the erosion rates in ways not been predicted by the BANCS model. Upon further inspection, the discrepancy appeared to lie within the NBS method used. Only one out of the seven methods has applied in the present study to all geomorphic conditions along the river. When graphed separately it became apparent that the variables associated with the BEHI rating are more effective predictor of bank erosion than NBS.

A comprehensive management strategy for the river suggests that the BEHI rating system may be included to assess the stream bank erosion condition and potential and should be continued in more extensive manner for several other segments. Other NBS methods can be applied to further assessment in order to determine whether NBS rating system is applicable in Bakreshwar River.

\section{Future studies}

A field based study, such as the one have completed for Bakreshwar River should be monitored and re-measured for as long as possible so the data points will be closer to an average for the natural range of conditions. Additional time studying Bakreshwar River's erosion rates and corresponding BEHI and NBS ratings will enhance this study's dataset and our understanding, accuracy and application of the BANCS model in this river. Considering the variability in the climate, soils, and riparian vegetation in comparison to Colorado and Yellowstone datasets, some modifications to the BANCS model could be made in order to incorporate multiple hydro physiographic regions. Additional data points from other watersheds within the same physiographic region (Rarh Bengal) as well as Bakreshwar river re-referenced cross sections would also be required to accurately predict erosion rates within the region. Long term studies of the Rarh Bengal hydro physiographic streams would also assist in accurately predicting an average/annual stream bank erosion curve for this area. Our 
attempt will be reported in the subsequent work (in process) detailing on this ground.

Acknowledgments The authors are like to express their sincere thanks to Dr. Surojit Let, Dr. Abhishek Bhattacharya, Dr. Priyanka Das, Dr. Sunil Saha, Kaustuv Mukherjee and Sib Hembrom for their fair and priceless field assistance.

\section{References}

Bagchi K, Mukerjee KN (1983) Diagnostic survey of West Bengal(s), Department of Geography, Calcutta University, Pantg Delta \& Rarh Bengal; pp 17-19, 42-58

Bandyopadhyay S, Saha S, Ghosh K, De SK (2013) Validation of BEHI model through field generated data for assessing bank erosion along the River Haora, West Tripura, India. Earth Sci India 6(3):126-135

Beach T (1994) The fate of eroded soil: sediment sinks and sediment budgets of agrarian landscapes in Southern Minnesota, 1851-1988. Ann Assoc Am Geogr 8(1):5-28

Biswas A (1987) Laterites and lateritoids of Rarh Bengal. In: Datye VS et al. (eds) Explorations in the tropics, Prof KD Dikshit felicitation volume committee, Pune, pp 48-54

Boggess W, Miranowski J, Alt K, Heady E (1980) Sediment damage and farm production costs: a multiple-objective analysis. North Cent J Agric Econ 2(2):107-112

Bull LJ (1997) Magnitude and variation in the contribution of bank erosion to the suspended sediment load of the River Severn, UK. Earth Surf Process Landf 22(12):1109-1123

Darby SE, Thorne CR (1996) Development and testing of river-bank stability analysis. J Hydraul Eng 122(8):443-454

Dingman SL (2009) Fluvial hydraulics. Oxford University Press Inc, New York

Dudley DR, Karr JR (2002) Ecological perspective on water quality goals. Environ Manage 5(1):55-68

Evans DJ, Gibson CE, Rossell RS (2006) Sediment loads and sources in heavily modified Irish catchments: a move towards informed management strategies. Geomorphology 79(1-2):93-113

Fox GA, Wilson GV, Simon A, Langendoen EJ, Akay O, Fuchs JW (2007) Measuring streambank erosion due to ground water seepage: correlation to bank pore water pressure, precipitation and stream stage. Earth Surf Process Landf 32:1558-1573

Ghosh KG (2015) Hydro-geomorphological appraisal of Bakreshwar river basin, eastern India. Un-published $\mathrm{PhD}$ thesis in Geography, Visva-Bharati University, Santiniketan, West Bengal, India

Hargrove BL, Johnson D, Snethen D, Middendorf J (2010) From Dust Bowl to Mud Bowl: sedimentation, conservation measures, and the future of reservoirs. J Soil Water Conserv 65(1):14A-17A

Harmar OP, Clifford NJ (2007) Geomorphological explanation of the long profile of the lower Mississippi River. Geomorphology $84: 222-240$

Jha VC (2005) Denudational processes and land form characteristics of lateritic terrain of Birbhum District, W.B., India. Trans J Instit Indian Geogr 27(1):19-29

Kean JW (2003) Computation of flow and boundary shear stress near the banks of streams and rivers. $\mathrm{PhD}$ Thesis, University of Colorado, Boulder

Knighton D (1998) Fluvial forms and processes. Arnold, London

Markowitz G, Newton S (2011) Using bank assessment for non-point source consequences of sediment (BANCS) model to prioritize potential stream bank erosion on Birch Creek, Shandaken, New York. Project Report: Ashokan Watershed Stream Management
Program (AWSMP), pp 5-31. www.ashokanstreams.org. Accessed 28 September 2010

Montgomery DR, Buffington JM (1997) Channel-reach morphology in mountain drainage basins. Geol Soc Am Bull 109(5):596-611

Naiman RJ, Decamps H (1997) The ecology of interfaces: riparian Zones. Annu Rev Ecol Syst 28:621-658

NEH (1988) National engineering handbook, US Department of Agriculture, Natural Resources Conservation Service, Part 630 hydrology, Chapter 6, stream reaches and hydrologic units. http://www.hydrocad.net/neh/630ch6.pdf. Accessed 12 August 2012

Nelson C, Flagor B, Keith K, Herron T (2009) Lower Coeur d'Alene riverbank stabilization prioritization. Kootenai-Shoshone soil and water conservation district and Idaho Department of Environmental Quality, Coeur d'Alene, Idaho. https://www. deq.idaho.gov/media/468380-_water_data_reports_surface_water_ water_bodies_lower_cda_riverbank_stabilization_prioritization. pdf. Accessed 12 August 2012

Nieber JL, Wilson BN, Ulrich JS, Hansen BJ, Canelon DJ (2008) Assessment of streambank and bluff erosion in the knife river watershed. Final Report Submitted to Minnesota Pollution Control Agency. http://www.lakesuperiorstreams.org/archives/ knife/assessment $\% 20$ of\%20streambank\%20and\%20bluff\%20ero sion $\% 20$ in $\% 20$ the $\% 20 \mathrm{knife} \% 20$ river\%20watershed.pdf. Accessed 29 September 2010

NYCDEP (2007) New York City Department of Environmental Protection, US Army Engineer Research Development Center, Cornell Cooperative-Ulster Country. Upper Esopus Creek Management Plan. Volume I-III. http://www.catskillstreams.org/ pdfs/esopus_smp_es.pdf, http://www.catskillstreams.org/pdfs/ Esopus volume II.pdf. Accessed 12 August 2012

O'Malley LSS (1914) Rivers of Bengal. Bengal District Gazetteers, Govt of West Bengal, Calcutta, pp 116-121 [Reprint (1996)]

Odum EP (1971) Fundamentals of ecology, 3rd edn. WB Saunders Company, Philadelphia

Paz AR, Collischonn W (2007) River reach length and slope estimates for large-scale hydrological models based on a relatively highresolution digital elevation model. J Hydrol 343:127-139

Rathbun J (2004) Standard operating procedure: Assessing bank erosion potential using Rosgen's Bank Erosion Hazard Index (BEHI). Water Bureau, Michigan Department of Environmental Quality, Lansing, MI. http://www.michigan.gov/documents/deq/ wb-nps-BEHI-SOP_246873_7.doc Accessed 07 November 2014

Riley AL (2008) Putting a price on riparian corridors as water treatment facilities. California Regional Water Quality Control Board San Francisco Bay Region http://www.floods.org/acefiles/Monetary_value_of_streams.pdf. Accessed 06 November 2014

Ringler NH, Hall JD (1975) Effects of logging on water temperature and dissolved oxygen in spawning beds. Trans Am Fish Soc 104:111-121. doi:10.1577/1548-8659(1975)104<111: EOLOWT $>2.0 . \mathrm{CO} ; 2$

Rosgen DL (1994) A classification of natural rivers. Catena 22:169-199

Rosgen DL (1996) Applied river morphology, 2nd edn. Wildland Hydrology Books, Pagosa Springs, CO

Rosgen DL (1998) The reference reach-a blueprint for natural channel design. In: ASCE conference, March 1998. http:// www.wildlandhydrology.com/assets/The_Reference_Reach_II. pdf Accessed 20 June 2010

Rosgen DL (2001) A practical method of computing streambank erosion rate. Wildland Hydrology, Pagosa Springs, Colorado. In: Proceedings of the seventh federal interagency sedimentation conference. March 25-29 2001. Reno, NV. 2 pp II 9-15. www. wildlandhydrology.com/assets/Streambank_erosion_paper.pdf/ 
www.wildlandhydrology.com/assets/CHANNEL_STABILITY_. pdf Accessed 19 June 2010

Rosgen DL (2006) A Watershed assessment for river stability and sediment supply (WARSSS). Wildland Hydrology Books, Fort Collins, Colorado. http://www.epa.gov/warsss/Accessed 20 June 2010

Rosgen DL (2008a) River stability field guide. Wildland Hydrology, Fort Collins

Rosgen DL (2008b) river stability forms and worksheets. Wildland Hydrology, Fort Collinss

Saha AK (1961) Geology of Birbhum. In: Roy B (ed) Census 1961, West Bengal, district census handbook. Govt of India, Birbhum, pp 9-10

Sass CK (2011) Evaluation and development of predictive streambank erosion curves for northeast Kansas using Rosgen's "BANCS" methodology. PhD Thesis, Kansas State University, Manhattan, Kansas

Schumn SA, Lichty RW (1963) Channel widening and floodplain construction along the Cimarron river in southwestern Kansas. US Geol Surv Prof Paper 352D:71-88

Sekely AC, Mulla DJ, Bauer DW (2002) Streambank slumping and its contribution to the phosphorus and suspended sediment loads of the Blue Earth River, Minnesota. J Soil Water Conserv 57(5):43-250

Simon A (1989) A model of channel response in disturb alluvial channels. Earth Surf Process Landf 14:11-26

Simon A (1992) Energy, time, and channel evolution in catastrophically disturbed fluvial systems. Geomorphology 5:345-372

Simon A, Darby SE (1999) The nature and significance of incised river channels. In: Darby SE, Simon A (eds) Incised river channels: processes, forms, engineering and management. Wiley, Chichester, pp 1-18

Simon A, Thorne CR (1996) Channel adjustment of an unstable coarse-grained alluvial stream: opposing trends of boundary and critical shear stress, and the applicability of extremal hypothesis. Earth Surf Process Landf 21:155-180
Simon A, Curini A, Darby S, Langenden E (1999) Stream bank mechanics and the role of bank and near-bank processes. In: Darby S, Simon A (eds) Incised river channels. Wiley, New York, pp 123-152

Thorne CR (1982) Processes and mechanisms of river bank erosion. In: Hey RD, Bathurst JC, Thorne CR (eds) Gravel-bed rivers. Wiley, Chichester, pp 227-271

Thorne CR (1999) Bank processes and channel evolution in northcentral Mississippi. In: Darby S, Simon A (eds) Incised river channels. Wiley, New York, pp 97-121

Upper Watts Branch Community Presentation (2012) Geomorphic assessment methodology and proposed analysis. Hazen and Sawyer: Environmental Engineers and Scientists. http://www. rockvillemd.gov/DocumentCenter/View/3201. Accessed 06 November 2014

US-EPA (2006) US Environmental Protection Agency (US-EPA). watershed assessment of river stability and sediment supply (WARSSS). http://water.epa.gov/scitech/datait/tools/warsss/pla_ box09.cfm Accessed 28 September 2010

US-EPA (2009) US Environmental Protection Agency (US-EPA). National water quality inventory: 2000 report (EPA-841-R-02001). www.epa.gov/305b Accessed 12 July 2010

Van Eps MA, Formica SJ, Morris TL, Beck JM, Cotter AS (2004) Using a bank erosion hazard index (BEHI) to estimate annual sediment loads from streambank erosion in the west fork white river watershed. Arkansas Department of Environmental Quality, Environmental Preservation Division, Little Rock

Williams JR, Smith CM (2008) Economic issues of watershed protection and rehabilitation. In: Hargrove WL (ed) Sedimentation in our reservoirs: causes and solutions. Kansas State University Agricultural Experiment Station and Cooperative Extension Service, Manhattan, KS. http://www.oznet.ksu.edu/ library/h20q12/KWRI_Book.pdf Accessed 29 September2010 